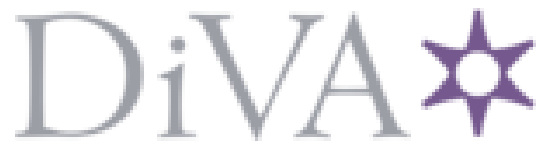

http://www.diva-portal.org

This is the published version of a paper published in Signs (Chicago, Ill.).

Citation for the original published paper (version of record):

Korolczuk, E., Graff, A. (2018)

Gender as 'Ebola from Brussels': The Anti-colonial Frame and the Rise of Illiberal

Populism

Signs (Chicago, Ill.), 43(3): 797-821

https://doi.org/10.1086/696691

Access to the published version may require subscription.

N.B. When citing this work, cite the original published paper.

Permanent link to this version:

http://urn.kb.se/resolve?urn=urn:nbn:se:sh:diva-39106 


\section{Gender as "Ebola from Brussels": The Anticolonial Frame and the Rise of Illiberal Populism}

n January 2015, on his way from Manila, Philippines, Pope Francis warned the faithful against "gender ideology" - a dangerous imposition from wealthy Western countries on developing nations. According to the pope, foreign aid and education are routinely tied to acceptance of gender equality policies; "this is the ideological colonization," he claimed, adding that "good and strong families" can overcome this trend (in O'Connell 2015). The pope has repeated these ideas many times since; for example, in Naples in 2015 and in Kraków in 2016, where he stated, "in Europe, America, Latin America, Africa, and in some countries of Asia, there are genuine forms of ideological colonization taking place. And one of these-I will call it clearly by its name-is [the ideology of] 'gender.' Today children — children! - are taught in school that everyone can choose his or her sex" (in Quinlan 2016, 1).

Such claims are not entirely new-anticolonial rhetoric has long been used as a strategy for both resisting and promoting gender equality, including in debates about feminism and women's rights in non-Western countries (e.g., Hoodfar 1997; Narayan 1997). The charge of colonialism has figured prominently in efforts to delegitimize conservative interventions by the US Christian Right in Malawi, Uganda, and Nigeria (Kaoma 2012). What is remarkable about the present scenario, however, is the extent to which the anticolonial frame as used by the Right is no longer about colonialism. It has evolved into a powerful metaphor for the arrogance of Western liberal elites, a discursive device divorced from actual colonial history, which is why it has worked in countries such as Poland. The conservative version of anticolonialism simply equates gender egalitarianism with colonization and often compares it with twentieth-century totalitarianisms and global terrorism, or even the deadly Ebola virus. We argue that this version of the anticolonial frame works in the service of illiberal populism by demonizing global elites

Elżbieta Korolczuk wishes to acknowledge that work on this article has been assisted by grant A78/2014 received from the Baltic Sea Fundation (project gender and political cultures of knowledge in Poland, Sweden, and Germany). Both authors would like to thank Ann Snitow, Barbara Einhorn, and Katheryn M. Detwiler for their comments on an early draft of this article.

[Signs: Journal of Women in Culture and Society 2018, vol. 43, no. 4]

(C) 2018 by The University of Chicago. All rights reserved. 0097-9740/2018/4304-0002\$10.00 
and claiming to come to the defense of ordinary people worldwide. ${ }^{1}$ Whereas previously antifeminist movements tended to ignore economics or to support free market capitalism (especially in the United States), since the 2008 financial crisis illiberal populist rhetoric has been gaining traction on the right in Europe and the United States.

This article analyzes antigenderism as a coherent ideological construction consciously and effectively used by right-wing and religious fundamentalists worldwide. In what follows we examine the basic tenets of antigenderism, shedding light on how it contributes to the contemporary transnational resurgence of illiberal populism. We argue that today's global Right, while selectively borrowing from liberal-Left and feminist discourses, is in fact constructing a new universalism, an illiberal one, that replaces individual rights with rights of the family as a basic societal unit and depicts religious conservatives as an embattled minority. ${ }^{2}$

With its nationalist rhetoric, which sometimes includes explicit racism and anti-Semitism, and its aggressive use of the language of "family values," this mobilization may appear as yet another resurgence of gendered nationalism or simply a continuation of decades-long right-wing resistance to gender egalitarianism as promoted by the United Nations and later the European Union. ${ }^{3} \mathrm{We}$, however, agree with scholars who have observed that the present wave of resistance involves new forms of organization and discourse, which allow "conservative actors to reach beyond their traditional circles and connect with a wider audience" (Paternotte 2014; see also Kováts and Põim 2015; Pető 2015; Kuhar and Paternotte 2017). What makes it new is the shift from conservative antifeminism, which focused on reproductive and sexual rights, to a much broader ideological construct that effectively combines a critique of liberal value systems (individualism, human rights, and gender equality) with opposition toward contemporary global capitalism (Pető 2015). Today's right-wing opposition to gender equality and feminism takes the form of a transnational political mobilization - an alternative illiberal civil society — based on an alliance between religious fundamentalists and illiberal populists. This alliance is facilitated by the persistent use of the

\footnotetext{
${ }^{1}$ We define "illiberal populism" as an ideological orientation based on "a nativist concept of belonging, linked to a chauvinist and racialized concept of 'the people' and 'the nation"” (Wodak 2015, 47), inherently antielitist and antiexpert, hostile to individualism and minority rights, which are the core tenants of liberal democracy (see also Ekiert [2012] on illiberal civil society and Zakaria [1997] on illiberal democracy).

${ }^{2}$ See, e.g., "World Family Declaration," World Congress of Families, n.d., http:// worldfamilydeclaration.org/.

${ }^{3}$ On gendered nationalism, see Yuval-Davis (1997), Einhorn (2006), Graff (2009), Ekiert (2012), and Wodak, KhosraviNik, and Mral (2013). On resistance to gender egalitarianism, see Buss (1998), Case (2011), Bob (2012), and Favier (2015).
} 
terms "gender" and "gender ideology" (aka "genderism"). These terms have become empty signifiers, flexible synonyms for demoralization, abortion, nonnormative sexuality, and sex confusion (Mayer and Sauer 2017), but they also stand for the ideology of global (neo)liberal elites (hence the significance of the anticolonial frame). "Genderism"- a term that sounds ominous and alien in most cultural contexts - has replaced "feminism" in global right-wing rhetoric, strengthening the critique of gender equality movements as powerful and foreign "colonizers."

We argue that despite its focus on issues of morality, antigenderism is in fact a political movement, which results from and responds to the economic crisis of 2008. The crisis revealed the weakness not only of the neoliberal economic model but also of liberal democracy as a space for processes of inclusion, equality, and freedom. Antigender mobilization is part of this process: antigenderists claim to represent true civil society, which aims to replace bureaucratized and alienated elites and their foreign-funded nongovernmental organizations (NGOs) and supranational institutions. The key ideologues (see, e.g., Peeters 2007, 2013; Kuby 2015) are self-proclaimed defenders of freedom and democracy, which in their view have been hijacked by liberals and leftists. Antigenderists effectively mobilize people gathered in existing national and local groups, churches, and political parties, and they are increasingly networking on the global level through international antichoice coalitions, organizations such as the World Congress of Families, and online petition platforms such as CitizenGo, which in December 2017 had over 8 million registered users worldwide. Grassroots antigender mobilization often takes the form of groups of self-proclaimed concerned parents protesting against what they perceive as state-imposed sexualization of children through sex education and gender equality training programs (Fábián and Korolczuk 2017; Höjdestrand 2017; Strelnyk 2017). The arguments promulgated by antigender ideologues must be understood as part of a global socially conservative ideoscape (Appadurai 1996), in which local actors draw heavily on each other's agendas while accommodating their claims and strategies to specific sociopolitical situations. While Eszter Kováts and Maari Põim (2015) demonstrate that resistance to gender has became a "symbolic glue" linking the programs and discourses of far-right and conservative parties in Europe, we show that it is the anticolonial frame that provides ideological coherence to an otherwise loose coalition of religious and national players worldwide. ${ }^{4}$ It is an important ingredient of today's illiberal populist turn.

\footnotetext{
${ }^{4}$ We employ the concept of framing following social movements scholars who identify frames as social schemata of interpretation that "render events or occurrences meaningful and thereby function to organize experience and guide action" (Benford and Snow 2000, 614). Framing theory highlights "the symbolic and meaning work done by movement activists as they
} 
The first part of this article presents our positionality and methods. The second part broadly discusses conceptualizations of antigender mobilization. The third and fourth sections develop a new way of theorizing this phenomenon, one that links different cases of mobilization with antigenderism as an ideological construct. We examine the right-wing use of an anticolonial frame, which we identify as antigenderism's key discursive structure. The fifth section discusses the far-reaching implications of this phenomenon for feminist theory and practice. We conclude with the claim that the opposition to gender is key for the ideological coherence of the present illiberal turn and that antigenderism has become a new language of resistance to neoliberalism. The appropriation of the anticolonial frame by global right-wing forces seriously limits discursive strategies available to the Left in response to neoliberalism.

\section{Positionality and methods}

The insights presented in this article are an outcome of our engagements as feminist scholars and activists working at the intersection of academia and civil society in Poland and Sweden. Our analysis results from participation in several collaborative projects, which emerged in response to antigender campaigns in the European context. As activists, we are affiliated with various initiatives, bodies, and organizations, some of which have been targeted by the antigender campaign. Since the outbreak of the "war on gender" in the Polish context around 2012 (Graff and Korolczuk 2017; see also Morska 2014), we have participated in a number of public debates and confrontations concerning "gender ideology" in Polish media and public institutions, and we have realized over time that we are witnessing a coordinated effort aimed at delegitimizing gender research and ultimately gender equality policies and projects. Occasionally, the subject of our analysis became part of our embodied experience: for instance, when we participated as observers in a demonstration against sex education in schools in September 2015 in Warsaw or when we faced a smoke bomb deployed by right-wing activists during a public debate on gender organized at the Dominican Church in Warsaw in the fall of 2013. In short, we are what antigenderists call "gender ideologues." Our aim, however, is not to debunk and ridicule but to understand. Committed to grasping the internal logic of our opponents' worldview and the sources of its mass appeal, we examine antigenderism as an ideology and moral sensi-

articulate grievances, generate consensus ... and present rationalities for their actions and proposed solutions to adherents, bystanders, and antagonists" (Williams 2008, 93). Antigenderists deploy symbols and identities that are key to postcolonial theory, but they do not subscribe to this theoretical strand; in fact, some may not even be aware of its existence. 
bility deeply at odds with our own but nonetheless deserving of scholarly attention. At times we quote antigenderists at length, giving them a chance to speak in their own voices.

This study builds on textual analysis of books and articles by key authorities in the European antigender circuit, including Gabriele Kuby (2015) and Marguerite Peeters $(2007,2013)$, as well as their Polish counterparts, such as Father Dariusz Oko and Marzena Nykiel (2014) and others (e.g., Benedict XVI et al. 2014). ${ }^{5}$ We have also examined interviews with, and public statements by, key proponents of antigenderism worldwide (including two popes and a number of local Catholic hierarchs and intellectuals, such as French priest and psychoanalyst Tony Anatrella or Guinean cardinal and prefect of the Congregation for Divine Worship and the Discipline of the Sacraments Robert Sarah), and we analyze media coverage of antigender events and various materials published on the websites of specific movements and organizations, such as the Polish network StopGender.pl or international platforms such as CitizenGo and Life Site News. Additionally, we have observed antigender rallies in Warsaw in 2015 and studied media reports and research on related mobilizations in other countries. These include the antiLGBT and antifeminist backlash in Vladimir Putin's Russia and in Ukraine and Georgia; demonstrations against marriage equality in France in 2014 ( $\mathrm{La}$ Manif Pour Tous); the rise of antigay violence and legislation in other regions, including some African countries (e.g., Uganda's Anti-Homosexuality Act of 2014); the role that controversies about gender equality played in the debates concerning the peace deal in Colombia in 2016; and the 2015 national debate on the use of public bathrooms by transgender people in the United States. What interests us is the ideological framework linking these seemingly divergent phenomena. While our analysis focuses mostly on the Polish case, we strive to reconstruct the key tenets of antigenderism as an ideology and strategy for social mobilization of relevance far beyond our local context.

\section{Continuity and change: Conceptualizing antigender mobilization}

Conservatives oppose gender on three levels: as a concept, as an ideology or theory, and as a social practice and political project (Case 2011; Favier 2015). In response, some scholars and commentators have employed broad terms such as "anti-gender mobilization" (Kováts and Põim 2015) or "the war against gender" (Korolczuk 2014). Others focus on specific facets of the trend, which they define as "anti-feminism" (Szelewa 2014), an attack on gen-

\footnotetext{
${ }^{5}$ See Dariusz Oko, "Wykład w Sejmie 23.01.2014" [Lecture before the Polish Parliament, January 23,2014 ], video uploaded by wybierzpolske, $2: 13: 45$, https://www.youtube.com /watch? $=\mathrm{gDMMuS} 32 \mathrm{ysE}$.
} 
der studies (Grabowska 2014), or opposition to gender equality (Hankivsky and Skoryk 2014), to gay marriage (Fassin 2014), or to "laws and policies concerning sexual and reproductive health and rights in the European Union" (Hodžić and Bijelić 2014, 1). While different terms are used, it is clear by now that this phenomenon is not a local anomaly but a transnational right-wing strategy, one that effectively employs the idea of the local and the authentic but is consistent and to some extent coordinated across borders. ${ }^{6}$

Due to its focus on reproductive rights, antigender mobilization has been interpreted as a continuation of resistance to feminism and as yet another stage in the culture wars - a global clash of promodern and antimodern sensibilities (see Bob 2012). In fact, antigenderists also use the term "culture war," presenting themselves as peaceful and besieged and warning against the alleged violence of genderists. For example, Kuby, a right-wing German sociologist, repeatedly uses combat-related words such as "weapon," "battle," "fight," and "threat," calling for resistance to "the 200-year cultural war to create autonomous, manipulable, controllable people" $(2015,17)$. A key issue in the culture wars has always been the politics of reproduction, as evidenced by the history of right-wing resistance to UN population policies. ${ }^{\text {? }}$ In recent decades these struggles have grown considerably more complex, partly because of fundamental changes in family configurations (e.g., families with same-sex parents and falling fertility rates in Europe) and partly due to developments in the field of reproductive technologies, perceived as a threat to the so-called natural order of things. In some contexts, antigender mobilization includes strong opposition to assisted reproduction; thus, it has been interpreted as reflecting an ideological conflict about the nature/culture frontier. Antigender pundits consider biomedical intervention in the human body to be an extension of Malthusianism and eugenics, both of which they see as the foundation of contemporary transnational gender policies (Nykiel 2014; Kuby 2015, 18-20). Over the years, antigender theorists have strengthened the economic aspect of their argument: they view themselves as defenders of ordinary people against the corporate greed of pharmaceutical companies seeking to sell contraception and the medical establishment offering abortion and in vitro fertilization (IVF; see, e.g., Nykiel 2014, 27-50).

Some scholars examining antigenderism assert that the core issue at stake is gender binarism and the fate of hegemonic masculinity. Much like religious fundamentalists struggling to eradicate sex education from US schools

${ }^{6}$ See, e.g., Korolczuk (2014), Paternotte (2014), Grzebalska (2015), Kováts and Põim (2015), and Kuhar and Paternotte (2017).

${ }^{7}$ See, e.g., Buss (1998), Buss and Herman (2003), Bob (2012), Omang (2013), and Favier (2015). 
(Irvine 2002), antigender campaigners in Poland are obsessed with the alleged threat to boys posed by sex educators who, according to right-wing media, have made them wear skirts (Graff 2014; Duda 2016, 27). Moral panics around the alleged destabilization of natural gender roles link anxieties about depopulation with grim visions of the end of patriarchy and men's power (often referred to as a "masculinity crisis"). Antigenderists promise to rejuvenate hegemonic masculinity and traditional fatherhood, which is why some masculinist movements, including Polish fathers' rights groups, have joined forces with antigender activists (Korolczuk and Hryciuk 2017).

Currently, the struggles over masculinity can be interpreted as a facet of a class conflict at the core of new nationalist extremisms, which became visible in the wake of the economic crisis of 2008. Antigenderism at least partly reflects the growing frustration of men with no economic prospects who turn to patriarchal values rather than address the economic sources of their misfortunes (see Tryczyk 2013). Such a perspective helps us understand why some far-right groups have joined the antigender crusade, but it is also important to avoid class reductionism. Antigenderism clearly feeds on anxieties arising from the permanent state of precariousness produced by neoliberalism. However, such sentiments appeal not only to economically disadvantaged populations but also - and in some contexts primarily - to the middle class.

Many scholars point to the crucial role of religious institutions, especially the Vatican, in combating gender equality (Buss and Herman 2003; Case 2011; Kuhar 2014). In fact, it seems worthwhile to think of the Vatican as the precursor to modern global institutions with enormous influence at the local level. This explains why the United Nations has been a target of attacks, as it is viewed as a powerful yet illegitimate competitor or, in fact, a usurper. Peeters warns that "the new concepts tend to occupy the space that should be occupied by evangelization. Christians preach human rights, sustainability and the Millennium Development Goals instead of preaching the gospel" $(2007,10)$. The conflict is thus not only about religion or ideological differences but also about power and legitimacy.

The Vatican's opposition to genderism is often interpreted as a continuation of the Church's war against the civilization of death and the resistance during the 1990s to what was then called the "gender agenda" (Butler 2004; Omang 2013; Favier 2015). What is new about the current phase is that the representatives of the clergy and Catholic commentators not only oppose women's reproductive rights and stress the connection between family planning and LGBT rights but also link both to the flaws of global capitalism. All three are said to be part of the same agenda, which is supposedly leading to the destruction of family and ultimately to "the destruction of man" (Case 
2011). Demonization of gender is also a novel strategy of the church to discipline liberal Catholics in the aftermath of the pedophilia scandals. According to Polish feminist theologian Zuzanna Radzik (2013), genderism has become the new enemy of the illiberal wing of the church, a generalized evil that has to some extent replaced Jews and homosexuals as groups that are vilified and accused of spreading corruption. In short, antigenderism appears to be a reaction to tensions within contemporary Catholicism and a new source of cohesiveness among Catholics. The conservative definition of the family has become a new frontier, while dissenters are now positioned as those who have abandoned faith.

Antigenderism, however, is much more than a reactionary trend within the Catholic Church: evangelical and orthodox Christians, as well as some Muslim and nondenominational groups, are also involved. We propose interpreting antigenderism as a political rather than a religious movement, one that effectively masks its political nature by appeals to dignity, theology, and moral values. Clifford Bob's (2012) research on global right-wing activism, which emerged in response to the gender equality agenda's being promoted on transnational level, shows that a loose-knit multidenominational network of organizations and groups had already begun to coalesce around "traditional" family values at the Fourth World Conference on Women in Beijing in 1995. This alliance gradually evolved into what Bob calls a "Baptist-burqa" network (36), an interfaith alliance that cooperates internationally on different policy goals. Specific aims have included defending conservative Christians persecuted for homeschooling their children in Germany, providing legal and ideological support for legislation outlawing abortion in Nicaragua, and speaking against gay rights in Uganda (Bob 2012, 37-38; Kaoma 2012). Antigender rhetoric has been used to oppose the 2016 peace deal in Colombia, which was rejected partly for mentioning gender equality and sexual rights and for including women's groups in the negotiations (Krystalli and Theidon 2016). It should be stressed, however, that not all groups that oppose feminism, gender equality, or sexual democracy fall into the category of antigenderists. What differentiates the antigender movement from extreme religious fundamentalists (such as ISIS in the Middle East or Boko Haram in Nigeria) is that the former rejects the use of violence and views itself as defender of democracy in its original and true form.

Examined from this political perspective, the current development of antigenderism reflects the nature of global civil society, which is ideologically diverse and conflict oriented, with differences cutting across institutions and borders, and with specific battles resulting in policy outcomes (Bob 2012, 5 7). This conceptual framework allows us to see transnational and local ideological and institutional connections. Locally, the movement often has a 
grassroots character and builds on context-specific concerns, for example, the antigender mobilization that emerged in Poland around 2012 was viewed by some as an effort to cover up pedophilia scandals that had involved Polish clergy (Sierakowski 2014), while the context of antigenderism's emergence in France was seen solely through the lens of struggles over marriage equality culminating in massive demonstrations of January 2013 (Fassin 2014). The key themes, however, such as the recurrent image of the child in danger and the critique of cosmopolitan elites, are commonly used by antigenderists around the globe. ${ }^{8}$ The activists and ideologues of the movement portray politics as evil and corrupt. By appealing to nostalgia for natural modes of living, they tap into the antipolitical ressentiment observed on both sides of the Atlantic (Bennett et al. 2013). The core of the movement is not theological but political; it is a brand of populism - an illiberal one.

A critique of modernity and progress is an important part of transnational antigender discourse, but a focus on culture and religion may be misleading in that it obscures some important political entanglements. Antigender alliances must be contextualized as part and parcel of global power struggles that are affected (and often disrupted) by tensions and realignments in international politics. We argue that the key to understanding the present phase of the culture wars is the post-1989 geopolitical landscape: Eastern Europe, Russia, and the global South are the key battlegrounds. While core documents of the movement include exhortations from the pope, and while the key proponents of antigenderism tend to be Western Europeans (e.g., Anatrella, Kuby, and Peeters), today the interests of the Vatican, US Christian fundamentalists, and European nationalists appear eerily convergent with those of Putin's Russia, which is perceived as a moral rejuvenator of the West. ${ }^{9}$ According to Kuby, "Russia is today the only country where there may be the possibility for church and state to rebuild the foundations of the family" (2014a, 1).

One vivid example of how antigenderism is contingent on global politics is the development of the World Congress of Families (WCF), a global network of profamily and prolife groups, founded in 1995 in the United States,

\footnotetext{
${ }^{8}$ In Poland, an important site of antigender mobilization was mass parental resistance to the government's plans to lower the compulsory school age from seven to six in 2009-15. Protesters joined forces with antigenderists, who were contesting sex education in schools and the ratification of the Council of Europe's convention on preventing and combating violence against women and domestic violence (Istanbul Convention). While the school-age controversy was specific to Poland, the campaign's main slogan, "Save the Little Ones!," as well as the imagery employed, resonated with conservative moral panics worldwide. In a variety of contexts, genderists have been portrayed as sexual predators who pose a deadly threat to children (Duda 2016, 187; Höjdestrand 2017).

${ }^{9}$ See Benedict XVI (2012).
} 
which today has more than forty official partner organizations around the world, including in Russia. All these groups are engaged in "efforts to protect the unborn, encourage marriage, reduce poverty, improve the health of children and adults, help orphans find homes, and eliminate human trafficking and prostitution." 10 American activists have closely cooperated with local groups in other countries, including Russia: they took part in organizing the first and the second World Demographic Summits, both of which took place in Russia (at the Russian State Social University in 2011 and in Ulyanovsk in 2012; see also Bob 2012, 42-43). On their website they take pride in the accomplishments of Russian partners: in the eyes of the American WCF leaders Russia epitomizes the last frontier of true "family values" because "at a time when Western governments are moving backward to a pagan worldview, Russia has taken a leadership role to advance the natural family." Close collaboration between neoconservatives from Russia and the United States in 2012 was put to the test by changes in the global geopolitical landscape, namely, the tensions between Russia and the United States/ European Union due to the crisis in Crimea in 2014 and then the developments in Syria. Consequently, American leaders decided to withdraw from organizing the biennial conference, which was to take place in 2014 in Moscow.

Like the Vatican, the WCF strives to become the counterweight to the United Nations, at least regarding population policies, but in the context of serious political tensions it has difficulty maintaining its identity as a global institution. The crisis in Eastern Ukraine has also significantly reduced the political opportunities for some local anti-EU, pro-Russian groups such as the Parental Committee of Ukraine (Strelnyk 2017). At the same time, new possibilities for transnational cooperation may open, as suggested by the words of admiration for Putin that had already been expressed by the thenpresidential candidate Donald Trump in 2013.

Clearly, what is at stake here is an uneasy balance between transnationalism and local embeddedness. What binds these actors together is a yearning for universalism, for a world order that would displace what they perceive as the moral degradation and relativism of the contemporary "modern godless states" (Benedict XVI et al. 2014, 4). Right-wing groups link this goal to struggles for national sovereignty and democracy, understood as "the real power of the people" (Bluhm 2016, 28).

\footnotetext{
${ }^{10}$ WCF Statement, n.d., World Congress of Families, http://www.worldfamilydeclaration .org/.

${ }^{11}$ Planning WCF, n.d., World Congress of Families, http://www.christiannewswire.com /news/372773850.html.
} 


\section{Defenders of the poor: How the Right reconfigures gender} as colonial imposition

We have identified three elements that constitute the ideological core of antigenderism: first is a set of convictions about the nature of man, natural law, and human dignity consistent with Christian dogma and radically antithetical to social constructionism. Although the base is theological, much care is taken to provide scientific grounding for antigender views of sex differences (neuropsychology, brain sex, etc.) and to argue that gender studies are a scientific hoax.

Second, there is a deeply pessimistic and consistently antimodernist narrative of Western intellectual, cultural, and social history. The West is said to have degenerated under the influence of Karl Marx, Friedrich Engels, Sigmund Freud, the Frankfurt School, feminism, and postmodernism; specific thinkers and activists (especially Margaret Sanger, Margaret Mead, and Alfred Kinsey) are presented as degenerates and semicriminals, guilty of innumerable lies. In Kuby's words, genderism is a movement "fuelled by Marxist philosophers, particularly of the Frankfurt School in Germany. In their view, sexuality was to be liberated from restrictive morality - even from the taboo of incest. Sex between children, as well as sex with children, was to be allowed in order to create a 'society without oppression'" (2014a). A strong connection is traced between 1968 counterculture antiwar movements and the sexual revolution, the ideology of gender, and Malthusianism. The core idea of antigenderism, Kuby states, is that "the deregulation of sexual norms leads to the destruction of culture" (2013). Postsocialist countries and the global South are said to be somewhat resistant to this cultural change. Today, claim antigenderists, they can save the West from spiritual and demographic suicide by defending what are presented as the original, universal Western values, which they refer to as Christian values and Christian civilization.

Third, they share an alarmist vision of the global distribution of power: neo-Marxist globalists are said to have taken over the world by means of blackmail and manipulation masked by benevolent talk about public health and human rights. This sinister global force, supposedly funded by transnational corporations such as Amazon and Google, is described as a new form of colonialism, the most vulnerable targets of which are developing nations in Africa. Again, Eastern Europe is accorded a special place in this geography of gender, as a part of the world that was largely untouched by the sexual revolution.

It is the third tenet of antigenderism-its self-definition as resistance to new forms of cultural colonialism and neoliberal exploitation-that we see as crucial. Antigenderists present themselves as protectors of the world's col- 
onized peoples, the disenfranchised and economically disadvantaged, whose livelihoods, authentic cultures, and traditional value systems are threatened by neoliberal globalization. An unexamined assumption underlying this worldview is that not only are local and authentic cultural identity always socially conservative and heteronormative but gender conservatism also constitutes this sovereign identity's essential core. Antigenderists view themselves as defenders of an oppressed majority, as in the interview in which the pope stresses that "colonizing empires ... seek to make peoples forget their own identity and make them (all) equal" (in O'Connell 2015). The alleged colonizers are feminists, transnational NGOs, international bodies such as the United Nations and European Union, the somewhat elusive "homosexual lobby," or the West in general, as well as the power of global markets driven by what the pope refers to as the "idolatry of money" (in Pacewicz 2016). In Kuby's (2013) words: "this global sexual revolution is now being carried out by power elites. These include international organizations like the United Nations and the European Union, with their web of inscrutable suborganizations; global corporations like Amazon, Google, and Microsoft; the big foundations like Rockefeller and Guggenheim; extremely rich individuals like Bill and Melinda Gates, Ted Turner, Georges Soros, and Warren Buffett; and non-governmental organizations like the International Planned Parenthood Federation and the International Lesbian and Gay Association.... And they all share one interest: to reduce population growth on this planet."

The key sites of neocolonial power are said to be transnational institutions: the United Nations, UNICEF, UNAIDS, the World Health Organization, and the World Bank, along with international foundations and associations, including the Global Fund to Fight AIDS, Tuberculosis, and Malaria (Nykiel 2014, 45; Höjdestrand 2017; Strelnyk 2017). Antigenderists are also deeply critical of existing civil society structures in the postsocialist region of Europe and so-called developing countries, where many NGOs were founded by Western donors in the 1990s. As Tova Höjdestrand (2017) shows, in the Russian context conservative grassroots parents' movement activists attempt to reconfigure the very notion of civil society along moral and religious coordinates, with patriotism, traditional religiosity, and the institution of heterosexual marriage as core values. This conservative, illiberal civil society legitimizes itself by reference to the will of the people, as expressed in demonstrations and petitions, with authentic values as opposed to dangerous abstractions promulgated by the corrupt elites (see Duda 2016, 21). The movement's attitude toward democracy, however, is deeply ambiguous. Antigenderists stress their reverence for democratic methods such as mass mobilization, citizens' initiatives, or referenda, but they oppose the very idea of democratic deliberation over the natural 
order of things: the gender order, marriage, filiation, reproduction, parental authority.

Global efforts that include reproductive health, family planning, gender equality, and sexual rights are seen as a cover-up for the Western neoMalthusian project. The global elites' alleged desire to prevent population growth by spreading homosexuality and killing the unborn is viewed as a legacy of the West's self-destructive fixation on sexuality (the legacy of Freud, Herbert Marcuse, Kinsey, and the cultural revolt of 1968). This message comes across with particular force when uttered by a native of Africa, such as Cardinal Robert Sarah, one of the key proponents of antigenderism worldwide. Sarah has repeatedly warned against colonization by gender, which he compares to fundamentalist Islamism and ISIS: "To use a slogan, we find ourselves between 'gender ideology and ISIS.' Islamic massacres and libertarian demands regularly contend for the front page of the newspapers" (in Montagna 2015). He has also gone on record claiming that "gender ideology" is "a deadly impulse that is being experienced in the world increasingly cut off from God through ideological colonialism" (in Mena 2016).

Antigenderists view family planning as stemming from corporate greed, which drives global capitalism. They interpret the UN's family planning and sexual and reproductive policies as a grand scale depopulation project imposed on national governments. Its alleged aim is to bring profits to what they call the "abortion industry" as well as to pharmaceutical companies that sell contraception and offer IVF. Genderism is seen as a global force, while resistance is always presented as local. Thus, the set of values that antigenderists aim to defend and preserve includes national sovereignty and economic autonomy. Global liberal forces are said to introduce eugenic depopulation politics especially in poor, underdeveloped countries in Africa and Asia in order to strengthen their own economic and political position (e.g., Peeters 2013). While this narrative is not new, today the anticolonial frame has been dissociated from discussions of actual colonialism. The metaphor reveals remarkable fluidity and adaptability. Depending on the context, it may or may not involve explicit racism and anti-Semitism; antigenderists often express openly racist views but simultaneously accuse their opponents of racism. For example, Kuby (2015) often quotes E. Michael Jones (2005), a notorious US-based anti-Semite and proponent of the claim that the sexual revolution is a Jewish conspiracy, but she carefully omits references to Jewish origins of the alleged global plot while repeatedly accusing genderist elites of racism.

Various aspects of the anticolonial frame are highlighted by different groups engaged in antigender mobilization. Its main function is to create an atmosphere of moral blackmail. Globally, the Western middle class is ac- 
cused of colonizing the world's poor by imposing liberal values. In postsocialist countries, where its key propagators include ultranationalist groups, antigenderism often takes on an explicitly racist form, while in the US context the charge of colonization becomes the charge of race-based eugenics. When identifying key players on the genderist side, Kuby points to "the rich and powerful of the United States, generally white Anglo-Saxon Protestants (WASPs), who perceived the danger of 'differential fertility.' They feared that the low birth rate of the upper class and the high birth rate of the underclass, especially blacks in the US and poor Third World countries, would cause them to lose political and economic power" (Kuby 2015, 17). Taken out of context, this passage could pass for left-wing anticolonial discourse, with its heightened race and class consciousness and its critique of population policies. This brings us to the question of the implications of the right-wing use of the anticolonial frame.

As many authors have pointed out, anticolonialism has historically taken many forms in different contexts: "It is sometimes associated with an ideology of racial liberation, ... it may accompany a demand for a recognition of cultural differences on a broad and diverse front, [and it] was often articulated in terms of a radical, Marxist discourse of liberation" (Ashcroft, Griffiths, and Tifflin 2000, 12; see also Warren 2017). Scholars who have examined the conservative uses of postcolonial theory in contemporary Poland conclude that a problem inherent within postcolonialism itself makes the seemingly hostile takeover unavoidable: namely, the tendency to essentialize cultures and to validate authenticity and the local at the expense of the foreign and universal (Snochowska-Gonzalez 2012; Bill 2014). ${ }^{12}$ They also highlight the tendency of postcolonial theory to define imperialism mainly in cultural terms while disregarding material reality (Snochowska-Gonzalez 2012, 720). Stanley Bill asserts that "postcolonial theory defends the specificity of local cultures but in doing so it risks falling into a form of 'culturalism'" $(2014,6)$. A similar argument about postcolonial theory is put forth by other scholars, such as Vivek Chibber, whose controversial book on subaltern studies predicts that "while postcolonialism presents itself as the new face of radical critique, as the leading edge of criticism in an age of global capitalism, its arguments resurrect key pillars of conservative ideology" (2013, 286). The case of Poland shows that the notion of colonization is infinitely pliable in right-wing discourse and that it can be effectively used in countries with no obvious colonial history as a powerful signifier for humiliation that needs to be resisted.

\footnotetext{
${ }^{12}$ For a comprehensive discussion of the relation between the postcolonial and the postsocialist/post-Soviet, see, e.g., Tlostanova (2012) and Kołodziejczyk and Şandru (2016).
} 


\section{Linking Ebola with Brussels: Poland as victim and savior}

The Polish case shows how eclectic the antigender discourse can be, capitalizing on a rhetoric of both victimhood and cultural superiority. This is exemplified by one of the banners displayed during a large anti-sex education rally held on August 30, 2015, in Warsaw. In crude English, the sign announced: "Gender + Convention about so called "violence against the women and violence in the family' this is the Ebola for Poland from Brussels." Ebola, a virus spread through contact with body fluids that causes vomiting, diarrhea, and rashes, is commonly associated with tropical regions of sub-Saharan Africa. In the context of the right-wing rally, the word "Ebola" epitomized fear of the abject and the racial other. By linking the horrible African disease with the European Union's gender-equality legislation (the Istanbul Convention), Polish right-wing populists strive to undermine generally positive attitudes toward the European Union. Brussels is positioned here as a colonizer and a source of contagion, as it spreads the virus of genderism, aiming to destroy the healthy body of the Polish nation.

The choice of an African disease may seem odd, but it is by no means accidental. Certain nationalist groups assert that Poles are being targeted because they are the last frontier of what they see as undamaged Christianity and true moral values in Europe, while the real purpose of global elites is to enable mass migration from Africa to Central and Eastern Europe (Nykiel 2014). The ultimate danger awaiting Poles is the destruction of the nation and the construction of a new type of multicultural and multiethnic society, which is envisioned as easily controllable and unable to oppose transnational institutions or local agents of what the Vatican often calls the "civilization of death." Such conspiracy theories are legitimate political currency in today's Poland, as exemplified by the public statement of Paweł Kukiz, a member of parliament and former presidential candidate who received over 20 percent of the popular vote in the first phase of the May 2015 elections. Commenting on the ongoing refugee crisis, he asserted that EU migration policies are in fact aimed at extermination of the Polish nation: "The plan is for Poles to be scattered around the world, and a compilation of different ethnic groups is supposed to live here. Such a society would be easy to manipulate and will create a "natural moat" [buffer zone] between the East and the West. Maybe we are supposed to just abandon these lands, maybe we are supposed to die out." ${ }^{\prime 3}$

\footnotetext{
${ }^{13}$ This quotation is drawn from "Paweł Kukiz: Prawdopodobnie imigranci z Afryki mają podzielić i osłabić Polski naród!" [Paweł Kukiz: It is likely that immigrants from Africa are meant to divide and weaken the Polish Nation!], video uploaded by Anty Multi-Kulti, May 21, 2015, 1:09, https:/ /www.youtube.com/watch?v=1IBJhgz2Tec.
} 
These two narratives - the one that identifies the peoples of Africa as victims of a global conspiracy and the one placing Poles in this role, a nation to be replaced by Africans - may appear to be mutually exclusive. In fact, however, they converge in their valorization of ethnic and national homogeneity and local rootedness, as well as in their vilification of Western elites. Gender ideology is perceived as an aggressive pseudoreligion, whose success depends on the previous uprooting of indigenous value systems. According to Kuby, "Rootless, dependent, malleable masses may be ready to celebrate a newglobal - savior. The cultural revolution of our time increasingly limits individual freedom and broadens the power of the state over the individual and of international organizations over the states - in the service of the financial oligarchy and for toppling the moral order" $(2015,278)$. Genderism is thus portrayed as a criminal plot aimed at demoralizing and eventually eradicating entire populations, but the definition of who is in danger is broad enough to encompass all traditional, heterosexual families around the globe.

Within the imagined moral geography of antigenderism, Central and Eastern Europe in general, and Poland in particular, enjoy a privileged position. Whereas some right-wing ideologues in the region have identified genderism as a leftover from communism (e.g., Nykiel and Oko), their view is in fact entirely consistent with the narrative of Western colonization expounded by others (e.g., Kuby and Peeters). The colonizer is not the West as such but the West whose healthy (Christian) core had already been destroyed by neo-Marxism and feminism in the 1960s. Eastern Europe and Poland are singled out as the region whose inhabitants are aware of the dangers of Marxism and communism and hence are able to oppose the global colonizers. Thus, the region is routinely praised for the strength of its resistance by both European and American figures. Kuby states: "A new totalitarianism is developing under the cloak of freedom. . . . Now the East European countries are becoming aware of this trend, and my book seems to be helping awaken people. The destruction has not gone as far here and people are motivated to resist it. My great hope is that these East European countries will become a stronghold of resistance in the European Union" $(2014 b, 1)$.

Such praise is much appreciated by local exponents of the movement. Nykiel, the prominent Polish antigender author, ends her book with a quotation from Jones's enthusiastic affirmation of Poland's special mission in the global culture war: "It is Poland's calling to save the West. Jan Sobieski came to Vienna with his cavalry and thus saved the West and saved Christianity. Now there is a new enemy at our gates. The new enemy is Wilhelm Reich and sexual education. The world looks to Poland with hope that Poland shall save the West once again" (in Nykiel 2014, 305). 
The excesses of right-wing rhetoric should not blind us to the political significance of such exchanges. For a long time, Poland and other postsocialist countries appeared to many Western observers as laggards with respect to gender equality and sexual democracy, but to the Right, we are the world's avant-garde and possibly a savior. Given the current rise of gendered nationalism and illiberal populism in countries such as the United States and France, it is high time to go beyond the view that liberal democracy will necessarily thrive worldwide. We argue that Poland has become a key battleground in a reactionary effort to save civilization from genderism not only because it is a Catholic country but also because here the Right has already been successful in mobilizing the anxieties resulting from neoliberal reforms by playing on antielitist resentment. Politically, what has followed the wave of antigenderism is the Law and Justice Party regime: an authoritarian and conservative version of the welfare state, with pronatalist policies, cash transfers to parents, and a strong focus on the heterosexual family (Graff and Korolczuk 2017). Thus, Poland should not be seen as an exceptional or provincial case but rather a paradigmatic one - and an important predictor for possible future developments in Western Europe.

\section{Discussion: Theoretical and political implications for feminism}

As an ideology, antigenderism interpellates subjects as victims of a global conspiracy, manipulated by the neoliberal elites targeting their true nature as men, women, and children, as mothers and fathers. This idea is used to present new religious conservatism and right-wing populism as legitimate and just, helping to mobilize individuals on a mass scale in what appear to be vastly depoliticized modern societies. This new ideological configuration, one that links gender conservatism and critiques of neoliberalism, has profound consequences for any attempt on the Left to develop effective strategies to counteract right-wing populism.

The consequences of our findings for feminist theory and organizing are urgent and somewhat unsettling. First, it is useful to consider certain intriguing affinities between antigender discourse and recent interventions in feminist theory concerning the relationship between feminism and neoliberalism. The antigenderist conceptualization of feminism, which equates it with rampant individualism and paints feminists as heralds of neoliberal globalization, is reminiscent of Nancy Fraser's influential argument about the "perverse subterranean elective affinity" between feminism and neoliberalism (2009, 108; see also Charkiewicz and Zachorowska-Mazurkiewicz 2009; Eisenstein 2009; McRobbie 2009). While acknowledging her critics' objections, which 
argue that her narrative overgeneralizes the faults of contemporary US feminism and elides the heterogeneity of women's movements worldwide (Aslan and Gambetti 2011; Funk 2013), we nonetheless share Fraser's concern that "the cultural changes jump-started by the second wave [of feminism], salutary in themselves, have served to legitimate a structural transformation of capitalist society that runs directly counter to feminist visions of a just society" $(2009,99)$. Her pessimistic diagnosis is accurate as far as the internationally successful part of Western feminism is concerned - precisely the part caricatured as colonialist by the antigender movement.

Leftist critics of feminism's affinity with, or seduction by, neoliberalism view the two as separate currents that converged in some contexts and at a certain point in time, a development they perceive as an unfortunate anomaly, a betrayal of the original spirit of feminism as a movement for social justice. This is also our view of the matter. From the right-wing perspective, the story is much simpler: feminism has always been part and parcel of the neoliberal project, which sells rampant individualism as emancipation, corroding community and family. Obviously, the proposed solutions to the neoliberal crisis are also irreducibly different: socialist reforms in one case and gender retraditionalization in the other. Where the two critiques of neoliberalism converge is in their concern with the undervaluing of care, the dismantling of welfare provisions, and the effects of these trends on women and families. We are profoundly skeptical about the possibility of dialogue or cooperation with antigenderists, but we do believe that the current political configuration opens up new possibilities for feminist strategizing. Paradoxically, rightwing populism has ushered the problematic of care and parenthood into public debate, which may be seen as an entry point for feminist activists to reclaim the territory of care, social provision, welfare, and community.

Our analysis may also have implications for the decades-long alliance between feminism and postcolonial theory. Our findings are compatible with some critiques of the inherent flaws of postcolonial theory, although they do not depend on them. It is of secondary importance to our study whether or not conservative uses of postcolonial theory are interpreted as a hostile takeover or as an inevitable effect of features of the theory itself (Warren 2017). The key point is that this emergent trend can effectively undermine the advances of transnational and local feminisms and of left-wing movements around the globe. Those on the liberal left who believe that postcolonial theory offers tools to counteract illiberal forces need to acknowledge that the anticolonial frame is routinely being put to use by right-wing forces and with remarkable success. To grasp the implications of this trend is to acknowledge that we are facing an entirely new political reality. 


\section{Conclusion}

Antigenderism is not just another wave of backlash, one that may be peculiar to the postsocialist context. Neither is it simply a new tactic of the Vatican in its ongoing efforts to undermine gender equality. It is not business as usual but a new ideological and political configuration, a transnational phenomenon with outposts in both the West and the East. While the backlash of the eighties and nineties combined neoconservatism with market fundamentalism (which is to some extent still the case with neoconservative Christian fundamentalists in the United States and elsewhere), the new wave of illiberal populism links gender conservatism with a critique of neoliberalism and globalization. This combination has remarkable ideological coherence and great mobilizing power: right-wing populists have captured the imagination and hearts of large portions of local populations more effectively than progressive movements have managed to do. The coherence of this worldview relies on three persistent equivalencies linking the cultural with the economic and the political: Western liberal elites are equated with the global political and economic elite; neoliberalism as a source of suffering and injustice is equated with individualism as a value system and ideological project; and finally population and gender-equality policies are interpreted as a new phase of global colonialism.

The anticolonial frame plays a central role in the war against gender and more broadly in the contemporary resurgence of illiberal populism. It is not just a rhetorical embellishment but a set of beliefs crucial to the coherence of antigenderism as an ideology and to the movement's identity as a coalition of diverse groups within and across national boundaries. It also affects the movement's strategic choices, alliances, and forms of mobilization.

First, the anticolonial frame determines targets selected for specific antigender campaigns: they tend to be transnational bodies and policies regarding gender equality. Antigenderism is deeply suspicious not only of global or transnational institutions but also of national governments, which are accused of collusion with genderists (e.g., by implementing transnational treaties on gender equality). Second, the anticolonial frame allows for alliances between nationalists in various locations: it is always the local, authentic, indigenous culture, the local traditional family (whatever its tradition) that is under threat and in need of protection. Anticolonialism is a populist metadiscourse that helps to trump local particularisms and geopolitical conflicts; it presents itself as an effort to defend ordinary people, the poor, the helpless, and the abused against a network of corrupt global elites. Finally, skillful use of the anticolonial frame allows for successful mobilization at the grassroots. It appeals to constituencies that had not previously construed themselves in 
political terms, such as parents. Conservative parenthood has emerged globally as a new political identity, a site of social solidarity, and a form of resistance to the state, transnational institutions, the market, and feminism, which is viewed here primarily as a form of individualism (Fábián and Korolczuk 2017). Within this framework, feminism is presented as an integral part of neoliberalism, while the traditional family becomes the last frontier of resistance, a place where there is still hope and a sense of community. It is a narrative with enormous affective power, one that endows subjects with a sense of dignity and collective agency while at the same time giving voice to anxiety that results from increasingly precarious working and living conditions under global capitalism.

Relying on an anticolonial frame, the Right has undermined the left-wing monopoly on voicing critiques of capitalism and has offered a new version of cultural universalism, an illiberal one. In short, antigenderism has become the new language of anticapitalist mobilization. This may seem paradoxical from the American perspective, given the persistent alliance between neoconservatism and neoliberalism in the United States (see Brown 2006), but the United States may be an exception rather than the rule. Globally, contemporary right-wing movements and ideologies tend to be illiberal and populist rather than neoconservative. At the core of their ideology is an equation between neoliberalism and individualism as a value system and ideological project that heralds human rights and gender equality to colonize the world's impoverished nations. In effect, right-wing critique of neoliberalism and globalization takes the shape of antifeminist mobilization and employs the anticolonial frame as its key discursive strategy.

With ultraconservatives claiming the language of anticapitalism and anticolonialism, what are the prospects for feminist mobilizations and vocabularies? While feminists, mostly from the global South, have long critiqued the discourse of universal human rights and the neocolonial elements in UN population policies, today it is clear that a wholesale rejection of universalism plays into the hands of right-wing populists. We do not offer a solution to this dilemma, but our analysis suggests the need to rethink feminist critiques of universalism in a world where the hegemony of liberal democracy can no longer be taken for granted.

School of Culture and Education

Södortorn University (Korolczuk)

American Studies Center

University of Warsaw (Graff) 


\section{References}

Appadurai, Arjun. 1996. Modernity at Large: Cultural Dimensions of Globalization. Minneapolis: University of Minnesota Press.

Ashcroft, Bill, Gareth Griffiths, and Helen Tifflin. 2000. Post-colonial Studies: The Key Concepts. 2nd ed. London: Routledge.

Aslan, Özlem, and Zeynep Gambetti. 2011. "Provincializing Fraser's History: Feminism and Neoliberalism Revisited." History of the Present 1(1):130-47.

Benedict XVI. 2012. “'Gender Theory' and the Threat to Civilization.” Pamphlet, the Fatima Center, Constable, NY. http://fatima.org/synod/about/LF324 -Gender-Theory.pdf.

Benedict XVI, Andrzej Bujak, Waldemar Chrostowski, Henryk Hozer, Krzysztof Feusette, Gabriele Kuby, Dariusz Oko, Leszek Sosnowski, and Aleksander Stępkowski. 2014. "Dyktatura Gender" [Dictatorship of gender]. Brochure, Biały Kruk, Kraków.

Benford, Robert D., and David A. Snow. 2000. "Framing Processes and Social Movements: An Overview and Assessment.” Annual Review of Sociology 26:611-39.

Bennett, Elizabeth A., Alissa Cordner, Peter Taylor Klein, Stephanie Savell, and Gianpaolo Baiocchi. 2013. "Disavowing Politics: Civic Engagement in an Era of Political Skepticism.” American Journal of Sociology 119(2):518-48.

Bill, Stanley. 2014. "Seeking the Authentic: Polish Culture and the Nature of Postcolonial Theory." Nonsite.org, no. 12. http://nonsite.org/article/seeking-the -authentic-polish-culture-and-the-nature-of-postcolonial-theory.

Bluhm, Katharina. 2016. "Modernization, Geopolitics, and the New Russian Conservatives." Arbeitspapiere des Osteuropa-Instituts (Abteilung Soziologie) [Working papers of the Osteuropa Institute (Department of Sociology)] 1/2016: 3-37.

Bob, Clifford. 2012. The Global Right Wing and the Clash of World Politics. New York: Cambridge University Press.

Brown, Wendy. 2006. "American Nightmare: Neoliberalism, Neoconservatism, and De-democratization." Political Theory 34(6):670-714.

Buss, Doris E. 1998. "Robes, Relics, and Rights: The Vatican and the Beijing Conference on Women." Social and Legal Studies 7(3):339-63.

Buss, Doris E., and Didi Herman. 2003. Globalizing Family Values: The Christian Right in International Politics. Minneapolis: University of Minnesota Press.

Butler, Judith. 2004. "The End of Sexual Difference?” In Undoing Gender, 174203. New York: Routledge.

Case, Mary Anne. 2011. "After Gender the Destruction of Man-the Vatican's Nightmare Vision of the 'Gender Agenda' for Law." Pace Law Review 31(3): 802-17.

Charkiewicz, Ewa, and Anna Zachorowska-Mazurkiewicz, eds. 2009. Gender i ekonomia opieki [Gender and economy of care]. Warsaw: Biblioteka Think Tanku Feministycznego.

Chibber, Vivek. 2013. Postcolonial Theory and the Specter of Capital. New York: Verso. 
Duda, Maciej. 2016. Dogmat ptci: Polska wojna z gender [Gender dogma: Polish war on gender]. Gdańsk: Katedra Wydawnictwo Naukowe.

Einhorn, Barbara. 2006. "Insiders and Outsiders: Within and Beyond the Gendered Nation." In Handbook of Gender and Women's Studies, edited by Kathy Davis, Mary Evans, and Judith Lorber, 196-213. London: Sage.

Eisenstein, Hester. 2009. Feminism Seduced: How Global Elites Use Women's Labor and Ideas to Exploit the World. Boulder, CO: Paradigm.

Ekiert, Grzegorz. 2012. "The Illiberal Challenge in Post-Communist Europe: Surprises and Puzzles." Taiwan Journal of Democracy 8(2):63-77.

Fábián, Katalin, and Elżbieta Korolczuk, eds. 2017. Rebellious Parents: Parental Movements in Central-Eastern Europe and Russia. Bloomington: Indiana University Press.

Fassin, Éric. 2014. "Same-Sex Marriage, Nation, and Race: French Political Logics and Rhetorics." Contemporary French Civilization 39(3):281-301.

Favier, Anthony. 2015. "Catholics and Gender: A Historical Approach." Books and Ideas, March 16. http://www.booksandideas.net/Catholics-and-gender.html.

Fraser, Nancy. 2009. "Feminism, Capitalism, and the Cunning of History." New Left Review, no. 56: 97-117.

Funk, Nanette. 2013. "Contra Fraser on Feminism and Neoliberalism." Hypatia 28 (1):179-96.

Grabowska, Magdalena. 2014. "Pomiędzy Gender Studies a 'Ideologią Gender' ” [Between gender studies and "gender ideology"]. Heinrich Böll Stiftung (Heinrich Böll Foundation), Warsaw. http://pl.boell.org/pl/2014/01/07/pomiedzy-gender -studies-ideologia-gender.

Graff, Agnieszka. 2009. "Gender, Sexuality, and Nation-Here and Now: Reflections on the Gendered and Sexualized Aspects of Contemporary Polish Nationalism." In Intimate Citizenships: Gender, Sexualities, Politics, edited by Elżbieta H. Oleksy, 133-46. London: Routledge.

- 2014. "Report from the Gender Trenches: War against 'Genderism' in Poland.” European Journal of Women's Studies 21(4):431-42.

Graff, Agnieszka, and Elżbieta Korolczuk. 2017. "'Worse Than Communism and Nazism Put Together': War on Gender in Poland.” In Anti-gender Campaigns in Europe: Mobilizing against Equality, edited by Roman Kuhar and David Paternotte, 175-93. Lanham, MD: Rowman \& Littlefield.

Grzebalska, Weronika. 2015. "Poland." In Kováts and Põim 2015, 83-103.

Hankivsky, Olena, and Marfa Skoryk. 2014. "The Current Situation and Potential Responses to Movements against Gender Equality in Ukraine.” East/West 1 (1):19-43.

Hodžić, Amir, and Nataša Bijelić. 2014. "Neo-conservative Threats to Sexual and Reproductive Rights in the European Union.” Report, CESI, translated by Zrinka Pavlić, Zagreb. http://www.cesi.hr/attach/_n/neo-conservative_threats_to_srhr_in _eu.pdf.

Höjdestrand, Tova. 2017. "Nationalism and Civicness in Russia: Grassroots Mobilization in Defense of 'Family Values.' ” In Fábián and Korolczuk 2017, 31-60. 
Hoodfar, Homa. 1997. "The Veil in Their Minds and on Our Heads: Veiling Practices and Muslim Women." In The Politics of Culture in the Shadow of Capital, edited by Lisa Lowe and David Loyd, 248-79. Durham, NC: Duke University Press.

Irvine, Janice M. 2002. Talk about Sex: The Battles over Sex Education in the United States. Berkeley: University of California Press.

Jones, E. Michael. 2005. Libido Dominandi: Sexual Liberation and Political Control. South Bend, IN: St. Augustine's Press.

Kaoma, Kapya John. 2012. “Colonizing African Values: How the U.S. Christian Right Is Transforming Sexual Politics in Africa.” Report, Political Research Associates, Somerville, MA.

Kołodziejczyk, Dorota, and Cristina Şandru. 2016. Postcolonial Perspectives on Postcommunism in Central and Eastern Europe. New York: Routledge.

Korolczuk, Elżbieta. 2014. “'The War on Gender' from a Transnational PerspectiveLessons for Feminist Strategising." In Anti-gender Movements on the Rise? Strategising for Gender Equality in Central and Eastern Europe, 43-53. Heinrich Böll Stiftung, Publication Series on Democracy, vol. 38. Berlin: Heinrich Böll Stiftung.

Korolczuk, Elżbieta, and Renata E. Hryciuk. 2017. "In the Name of the Family and Nation: Framing Fathers' Activism in Contemporary Poland.” In Fábián and Korolczuk 2017, 113-44.

Kováts, Eszter, and Maari Põim, eds. 2015. “Gender as Symbolic Glue: The Position and Role of Conservative and Far Right Parties in the Anti-gender Mobilizations in Europe." Report, Foundation for European Progressive Studies in cooperation with Friedrich-Ebert-Stiftung, Budapest. http://www.feps-europe.eu/assets /cae464d2-f4ca-468c-a93e-5d0dad365a83/feps-gender-as-symbolic-glue-wwwpdf .pdf.

Krystalli, Roxanne, and Kimberly Theidon. 2016. "Here's How Attention to Gender Affected Colombia's Peace Process." Washington Post, October 9. https://www .washingtonpost.com/news/monkey-cage/wp/2016/10/09/heres-how -attention-to-gender-affected-colombias-peace-process/?utm_term $=.8194456 \mathrm{bd} 447$.

Kuby, Gabriele. 2013. "Europe's Cassandra: German Sociologist Gabriele Kuby Discusses Conversion, the Global Sexual Revolution, Freedom, Family, and Faith." Interview by Alvino-Mario Fantini. Catholic World Report, August 14. http://www .catholicworldreport.com/Item/2501/europes_cassandra.aspx.

- 2014a. "Genderism - a New Ideology Destroying the Family." Life Site News, September 22. https://www.lifesitenews.com/opinion/genderism-a-new-ideology -destroying-the-family.

- 2014b. "The Global Sexual Revolution and the Assault on Freedom and Family." Catholic World Report, September 8. http://www.catholicworldreport.com /Item/3357/the_global_sexual_revolution_and_the_assault_on_freedom_and _family.aspx.

. 2015. The Global Sexual Revolution: Destruction of Freedom in the Name

of Freedom. Translated by James Patrick Kirchner. Kettering, $\mathrm{OH}$ : Angelico Press. 
Kuhar, Roman. 2014. "Playing with Science: Sexual Citizenship and the Roman Catholic Church Counter-narratives in Slovenia and Croatia." Women's Studies International Forum 49: 84-92.

Kuhar, Roman, and David Paternotte, eds. 2017. Anti-gender Campaigns in Europe: Mobilizing against Equality. London: Rowman \& Littlefield.

Mayer, Stephanie, and Birgit Sauer. 2017. " 'Gender Ideology” in Austria: Coalitions around an Empty Signifier." In Kuhar and Paternotte 2017, 23-40.

McRobbie, Angela. 2009. The Aftermath of Feminism: Gender, Culture, and Social Change. London: Sage.

Mena, Adelaine. 2016. 'Resist 'Ideological Colonization,' Cardinal Sarah Urges at Prayer Breakfast." Catholic News Agency, May 18. http://www.catholicnewsagency .com/news/resist-ideological-colonization-cardinal-sarah-urges-at-prayer-breakfast $-68951 /$.

Montagna, Diane. 2015. "Synod Fathers: From Hollywood to Gender Ideology to ISIS.” Aleteia, October 13. http://aleteia.org/2015/10/13/synod-fathers-from -hollywood-to-homosexuality-fantasy-games-to-fundamentalism/.

Morska, Izabela. 2014. "Globalny Spisek i Obrona Konieczna” [Global conspiracy and self-defense]. Krytyka Polityczna [Political critique], February 5. http:// www.krytykapolityczna.pl/artykuly/opinie/20140205/morska-globalny-spisek-i -obrona-konieczna.

Narayan, Uma. 1997. Dislocating Cultures: Identities, Traditions, and Third World Feminism. New York: Routledge.

Nykiel, Marzena. 2014. Putapka Gender: Karty kontra Orty [Gender trap: Dwarfs versus eagles]. Kraków: M Publishers.

O'Connell, Gerard. 2015. "Full Transcript of Pope's Press Conference on Flight from Manila." America, January 19. http://americamagazine.org/content/dispatches /full-transcript-popes-press-conference-flight-manila.

Omang, Joanne. 2013. "Playing Hardball against Women's Rights: The Holy See at the UN." Conscience 34(2):19-21.

Pacewicz, Piotr. 2016. "Co Franciszek powiedział biskupom?” [What did Pope Francis say to the bishops?]. OKO.press, August 4. https://oko.press/franciszek -powiedzial-biskupom-dokument-ktory-musisz-przeczytac/.

Paternotte, David. 2014. "Christian Trouble: The Catholic Church and the Subversion of Gender." CritCom, May 8. http://councilforeuropeanstudies.org /critcom/christian-trouble-the-catholic-church-and-the-subversion-of-gender/.

Peeters, Marguerite A. 2007. "The New Global Ethic: Challenges for the Church." The Institute for Intercultural Dialogue Dynamics. http://www.laici.va/content /dam/laici/documenti/donna/filosofia/english/new-global-ethic-challenges-for -the-church.pdf.

. 2013. Le Gender, une norme mondiale? Pour un discernement [Gender, the global norm? Toward an understanding]. Paris: MamE.

Petö, Andrea. 2015. "Epilogue: 'Anti-gender' mobilisational Discourse of Conservative and Far Right Parties as a Challenge for Progressive Politics.” In Kováts and Põim 2015, 126-31. 
Quinlan, Casey. 2016. "Pope Calls Teaching about Gender Identity 'Ideological Colonization.'” ThinkProgress, August 4. https://thinkprogress.org/pope-calls -teaching-about-gender-identity-ideological-colonization-e2207eaf5784 \#.k32ic4r5l.

Radzik, Zuzanna. 2013. "Skąd się bierze nagonka na gender czyli przepis na wroga" [Origins of campaign against gender or how to make an enemy]. Tygodnik Powszechny [Catholic weekly] 44: 33-56.

Sierakowski, Sławomir. 2014. "The Polish Church's Gender Problem.” New York Times, January 26. http://www.nytimes.com/2014/01/27/opinion/sierakowski -the-polish-churchs-gender-problem.html?_r $=4$.

Snochowska-Gonzalez, Claudia. 2012. "Post-colonial Poland-on an Unavoidable Misuse." East European Politics and Societies 26(4):708-23.

Strelnyk, Olena. 2017. “Conservative Parents’ Mobilization in Ukraine.” In Fábián and Korolczuk 2017, 61-90.

Szelewa, Dorota. 2014. "The Second Wave of Anti-feminism? Post-crisis Maternalist Policies and the Attack on the Concept of Gender in Poland." Gender a výzkum/ Gender and Research 15(2):33-47.

Tlostanova, Madina. 2012. "Postsocialist $\neq$ Postcolonial? On Post-Soviet Imaginary and Global Coloniality." Journal of Postcolonial Writing 48(2):130-42.

Tryczyk, Mirosław. 2013. "Nadchodzą wilki" [The wolves are coming]. Interview by Dorota Wodecka. Gazeta Wyborcza, December 6. http://wyborcza.pl/magazyn /1,124059,15090211,Nadchodza_wilki.html.

Warren, Rosie, ed. 2017. The Debate on "Postcolonial Theory and the Specter of Capital." London: Verso.

Williams, Rhys. 2008. "The Cultural Contexts of Collective Action: Constraints, Opportunities, and the Symbolic Life of Social Movements." In The Blackwell Companion to Social Movements, edited by David A. Snow, Sarah A. Soule, and Hanspeter Kriesi, 91-115. Malden, MA: Blackwell.

Wodak, Ruth. 2015. The Politics of Fear: What Right-Wing Populist Discourses Mean. London: Sage.

Wodak, Ruth, Majid KhosraviNik, and Brigitte Mral, eds. 2013. Right-Wing Рориlism in Europe: Politics and Discourse. London: Bloomsbury Academic.

Yuval-Davis, Nira. 1997. Gender and Nation. London: Sage.

Zakaria, Fareed. 1997. "The Rise of Illiberal Democracy.” Foreign Affairs 76(6): 22-43. 